УДК 811.11'42 : 159.946 .3

\title{
ПЕРСУАЗИВНИЙ КОМПОНЕНТ ЦИФРОВОЇ ПУБЛІчНОї ДИПЛОМАТІї
}

\section{Скрябіна Вікторія Борисівна}

кандидат філологічних наук, доцент,

Київський національний лінгвістичний університет, м. Київ, Украӥна

ORCID: 0000-0002-3793-3643

skryabina.ya@gmail.com
Надіслано:

10.03.2019

Рецензовано:

20.03.2019

Прийнято:

15.04.2019

Метою статті є дослідження персуазивності в цифровому публічному дипломатичному дискурсі. Персуазивний компонент досліджуємо за допомогою дискурсивного, семантичного, синтаксичного, а також стилістичного аналізів. Імпліцитні смисли дипломатичної комунікації встановлюємо, користуючись методами прагмалінгвістики. У результаті дослідження надано визначення цифрової публічної дипломатії як комунікативного явища, що здійснюється 3 використанням веб- та інформаційно-комунікаційних технологій. Встановлено прагматичні інтенції цифрового публічного дискурсу, серед яких передача офіційної позиції та формування іміджу держави за допомогою інтернет-мережі. Цифрова публічна дипломатія або твіпломатія сприяє відкритості і доступності міжнародної діяльності, дозволяє охопити широку аудиторію, здійснювати на неї персуазивний вплив. Зокрема,в статті докладно проаналізовано експліцитні та імпліцитні мовні засоби персуазивного впливу, які використовує на своїй сторінці в Twitter теперішній президент США Дональд Трамп, формуючи зовнішню політику країни з урахуванням інтересів американських виборців. Серед персуазивних лексичних засобів варто відзначити емоційно-забарвлену лексику та кліше, фразові дієслова та колоквіалізми, які надають особливу тональність президентським твітам, відтворюючи емоційність тапрямолінійність стилю Трампа. Використання граматичних засобів персуазивності (найвищого ступеню порівняння прикметників і прислівників, інтенсифікаторів, окличних речень) допомагає виразити гіперболізованість оцінок та категоричність стилю Дональда Трампа. У публічній дипломатії американський президент практично не використовує стилістичні засоби, лише деякі епітети, стерті метафори,повтори й асонанс. Здобуті результати сприяють подальшій науковій розробці проблеми персуазивної комунікації, в цифровій дипломатії зокрема. 
Ключові слова: персуазивність; цифрова публічна дипломатія; твіпломатія; ефект парасоціальної інтеракції.

Skriabina Viktoriia, Candidate of Linguistics, Associate Professor, Kyiv National Linguistic University, Kyiv, Ukraine

\section{Persuasive component of digital public diplomacy}

The objective of the article is to study persuasion in the digital public diplomatic discourse. Discursive, semantic, syntactic, and stylistic analyses have been employed to carry out the research of the persuasive component. The methods of pragmalinguistics have been used to establish implicit meanings in diplomatic communication. As a result of the study, the definition of digital public diplomacy as a communicative phenomenon implemented by using web as well as information and communication technologies has been given. The pragmatic intentions of digital public discourse have been established, including the presentation of the official position and the state image making in the Internet. Digital public diplomacy or twiplomacy helps to make international activities open and accessible to the public, as well as to persuade them. In particular, the explicit and implicit language means of persuasive influence used by the current US President Donald Trump on his Twitter page to form the country's foreign policy while taking into account the interests of American voters are analyzed in detail. Among lexical persuasive means loaded vocabulary and clichés, phrasal verbs and colloquialisms should be mentioned. They give special tone to presidential tweets reproducing Trump's emotional and straightforward style. The use of grammatical means of persuasion (the superlative degree of comparison of adjectives and adverbs, intensifiers, exclamatory sentences) helps to express Donald Trump's hyperbolic and categorical evaluation of events. At the same time, the American president practically does not use stylistic means, except for some epithets, dead metaphors, repetitions and assonance. The obtained results contribute to further scientific development of the problem of persuasive communication, in particular, in digital diplomacy.

Key words: persuasion; digital public diplomacy; twiplomacy; parasocial interaction effect.

Скрябина Виктория Борисовна, кандидат филологических наук, доцент, Киевский национальный лингвистический университет, Киев, Украина

\section{Персуазивный компонент цифровой публичной дипломатии}

Целью статьи является исследование персуазивности в цифровом публичном дипломатическом дискурсе. Персуазивный компонент исследуем с помощью дискурсивного, семантического, синтаксического, а также стилистического анализа. Имплицитные смыслы дипломатической коммуникации установлены с помощью методов прагмалингвистики. 


\section{Скрябіна Вікторія Борисівна \\ Персуазивний компонент \\ цифрової публічної дипломатії}

В результате исследования дано определение цифровой публичной дипломатии как коммуникативного явления, осуществляемого с использованием веб- и информационно-коммуникационных технологий. Установлены прагматические интенции цифрового публичного дискурса, среди которых передача официальной позиции и формирование имиджа государства посредством интернет-сети. Цифровая публичная дипломатия или твипломатия способствует открытости и доступности международной деятельности, позволяет охватить широкую аудиторию, оказать на нее персуазивное воздействие. В частности, в статье подробно проанализированы эксплицитные и имплицитные языковые средства персуазивности, которые использует на своей странице в Twitter нынешний президент США Дональд Трамп, формируя внешнюю политику страны с учетом интересов американских избирателей. Среди персуазивных лексических средств следует отметить эмоционально-окрашенную лексику и клише, фразовые глаголы и колоквиализмы, которые придают особую тональность президентским твитам, воспроизводя эмоциональность и прямолинейность стиля Трампа. Использование грамматических средств персуазивности (высшей степени сравнения прилагательных и наречий, интенсификаторов, восклицательных предложений) помогает выразить гиперболизированость оценок и категоричность стиля Дональда Трампа. В свою очередь в публичной дипломатии американский президент практически не использует стилистических средств, за исключением немногочисленных эпитетов, стертых метафор, повторов и ассонанса. Полученные результаты способствуют дальнейшей научной разработке проблемы персуазивной коммуникации, в частности в цифровой дипломатии.

Ключевые слова: персуазивность; цифровая публичная дипломатия; твипломатия; эффект парасоциальной интеракции.

\section{Вступ}

Проблема комунікації, комунікативного впливу є однією з центральних у сучасній лінгвістичній науці. Феномен комунікації включає індивідуальний і суспільний аспекти та є настільки об’ємним, що його досліджують практично всі науки. Персуазивність як різновид комунікативного впливу є невід’ємним компонентом дипломатії.

\section{Аналіз останніх досліджень і публікацій}

Мовленнєвий вплив у різних типах інституційного дискурсу вивчали А. М. Баранов, Р. Лакофф, О. М. Леонтьєв, Й. А.Стернін, В. Є. Чернявська, O.I.Шейгал, проте дипломатичний дискурс в залишається практично невивченим. Окремі аспекти дипломатичних текстів розглядали Е. Сатоу, 
Міжнародні відносини: теоретико-практичні аспекти

Випуск 4 (2019)

ISSN (print) 2616-745X; ISSN (online) 2616-7794

Х. Вільднер, Дж. Вуд та Ж. Серре. Серед українських дослідників варто відзначити праці Н. М. Поліщук та О. М. Мацько.

Публічна дипломатія як різновид дипломатичного дискурсу покликана забезпечити сприйняття політики однієї країни громадською думкою інших країн. На відміну від традиційної дипломатії, яка $є$ каналом спілкування між урядами, культурно-гуманітарні та інформаційні заходи публічної дипломатії спрямовані на широку аудиторію.

\section{Виділення невирішених раніше частин загальної проблеми. Формулювання цілей статті}

У статті ставимо за мету з'ясувати сутність феномену персуазивності в публічному дипломатичному дискурсі. Досягнення поставленої мети передбачає уточнення понять «цифрова публічна дипломатія» та «твіпломатія», виокремлення їхніх характерних ознак та встановлення мовних засобів впливу, використаних з метою переконання.

\section{Виклад основного матеріалу дослідження}

Термін «публічна дипломатія» вперше у 1965 р. використав відомий дипломаті декан Школи права і дипломатії ім. Флетчера Університету Тафта Едмунд Джулліон (Cull, 2006).

За концепцією Е. Джулліона, до завдань публічної дипломатії входить вивчення впливу суспільних відносин на формування та здійснення зовнішньої політики. Як і традиційна дипломатія, публічна дипломатія розглядає процес формування громадської думки в зарубіжних країнах; взаємодію інтересів однієї країни з іншою; відомості про стан міжнародних справ та їхній вплив на політику; комунікацію між дипломатами та іноземними журналістами, міжкультурну комунікація загалом.

Більш новим є термін «цифрова дипломатія», або «дипломатія Веб 2.0 », який використовують для позначення веб- та інформаційно-комунікаційних технологій у процесі дипломатичної комунікації (Trophymenko, Balabanov, 2013).

На відміну від традиційної публічної дипломатії, до якої відносять інформаційну пропаганду за допомогою засобів мас медіа; надання освіти населенню, проведення виставок для розповсюдження та просування політичної культури, цифрова дипломатія передбачає,насамперед, поширення друкованої та аудіовізуальної інформації у мережі інтернет, відслідковування блогів зарубіжних країн; створення сторінок державних установ, посольств та інших організацій, а також персоніфікованих сторінок членів уряду, послів у соціальних мережах; розсилку інформації через мобільні телефони тощо (Trophymenko, Balabanov,2013).

Цифрову дипломатію має практичний характер, її використовують для роботи із зарубіжними читачами, для трансляції офіційної позиції та з метою 
формування іміджу країни. У наш час, коли інформація чи дезінформація поширюються надзвичайно швидко, особливо гостро стоїть проблема залучення підтримки громадськості. Публічна дипломатія передбачає комунікацію в соціальних мережах. Твіпломасі (від назви соціальної мережі Twitter; англ. twitter - цвірінькати, щебетати) - так називають процес взаємодії державних органів, політичних, державних, громадських діячів однієї країни із громадськістю іншої за допомогою соціальної мережі Twitter. Twitter, Facebook та інші соціальні мережі допомагають «твіпломатам» здійснювати міжнародну діяльність і формувати зовнішню політику.

Публічнй дипломатичнй дискурс характеризується інтердискурсивністю, наявністю масового адресата, використанням кооперативних та конфронтативних стратегій, ритуалізованістю, діалогічністю, а також персуазивністю (Skriabina, 2018). Функція персуазивності об’єднує дипломатичний дискурс з політичним, релігійним та рекламним дискурсами. За В.Є. Чернявською, персуазивність - це здійснення впливу адресанта на думку, враження, ставлення, почуття, емоції адресата (Chernjavskaja, 2006, p. 25). Персуазивністю називають також певний вплив автора усного чи письмового повідомлення на його адресата 3 метою переконання в чомусь, заклику до певних дій (Golodnov, 2003). Ключовою ознакою та відмінною рисою його $є$ наявність дихотомії раціонального переконання і емоційно-маніпулятивного зваблювання реципієнта (Perelman, 2000), який здійснюють за допомогою переважно вербальної комунікації.

Вербальна комунікація виконує головну роль у будь якому виді людської діяльності (Pocheptsov, 2001, р.319). Мовлення є одним 3 найефективніших інструментів для забезпечення взаєморозуміння між людьми, але також слугує «таємним джерелом влади» (Azhezh, 2006, p. 192), яке дозволяє впливати на події.

Мова дипломатії допомагає сформувати суспільну думку щодо міжнародних проблем, мобілізує до виконання «політично-правильних» дій. У цифровій дипломатичній комунікації цю функцію реалізують за допомогою спеціальних маркерів, експліцитно, а також імпліцитно, через ідеологічні конотації політичних термінів, тональність всього дискурсу, особливий підбір оцінної лексики (Terentij, 2010, р. 50).

Цифрову публічну дипломатію можна назвати однією з найефективніших в аспекті персуазивного впливу. Цьому сприяють декілька факторів.

По-перше, стосунки адресант - адресат в цифровій публічній дипломатії мають свої особливості. Така комунікація $\epsilon$ асиметричною, оскільки незважаючи на те, що певний зворотний зв'язок (у вигляді вподобань та коментарів) існує, зміни комунікативних ролей по-суті немає: власнику 
сторінки належить більша комунікативна вага та дискурсивна ініціатива (Burkart, 1998, p 167).

Керівники держав та урядів все частіше беруть участь у вирішенні міжнародних проблем, завдяки чому особливого значення набувають особисті якості учасників дипломатичних перемовин, а неформальне спілкування займає значну часту переговорного процесу. Як наслідок, персуазивності цифрової дипломатії сприяє ефект парасоціальної інтеракції (Merten, 1977, p. 145; Jäckel, 1995, p. 470), в результаті якого в читачів веб-сторінки дипломата виникає ілюзія знайомства і особистого спілкування з ним, що викликає довіру до нього та, відповідно, до його повідомлень.

Завдяки впливу цифрових технологій сучасна дипломатія стала більш відкритою і доступною. Це дозволяє охоплювати і впливати на більш широку аудиторію. Так, проста зрозуміла мова допомагає публічним діячам на своїх інтернет-сторінках демонструвати некорумпованість, викликає в читачів відчуття, що вони знають політика особисто та поділяють його позицію.

Важливим інструментом персуазивності публічного дипломатичного дискурсу є також тональність повідомлення. Тональність як «стиль дискурсу» відображає стосунки між комунікантами та відображає ступінь їхньої формалізованості, наявність ієрархії, схожість чи відмінність особистісних характеристик (Halliday, 1978, p.33). Іншими параметрами тональності є серйозність / несерйозність, ужитковість / ритуальність, інформативність / фасцинативність, конструктивність / конфліктність, пряме / непряме вираження інтенцій (Karasik, 2002, p. 278).

Розглянемо, як використовує персуазивний потенціал цифрової публічної дипломатії для пропаганди своїх ідей 45-й президент США Дональд Трамп. Варто зазначити, що теперішній президент Сполучених Штатів володіє авторитарним стилем спілкування, навмисно ігнорує соціальні табу і поділяє світ на «сильних» і «слабих». Трамп виставляє напоказ свою успішну ділову кар'єру, відкрито демонструє свою маскулинність та уміння користуватися сучасними технологіями (Edsall, 2015).

Саме тому цікавою $\epsilon$ його сторінка в Твіттері, що вже давно перетворилася на головний канал його спілкування із зовнішнім світом,оскільки дозволяє йому не рахуватися 3 порадами професійних дипломатів з Держдепартаменту, які намагаються якимось чином згладити його риторику. Зміст і стиль дипломатії президента Трампа полягає у відмові від принципу багатосторонності; пріоритеті особистих стосунків у міжнародних відносинах; дотримання принципів традиційної політики ізоляціонізму, який передбачає превалювання національних інтересів над міжнародними (Landale, 2018). 
До основних лексичних засобів персуазивності, які використовує Дональд Трамп, у своїй віртуальній риториці відносимо емоційно-забарвлену лексику та кліше, які він активно використовує на позначення політичної ситуації в Афганістані, Сирії, Ірані (a total mess, financial chaos, a source of potential danger and conflict, economy is crashing, the terrible Iran Nuclear Deal, horrendous relationship). При цьому американський президент використовує комунікативну стратегію позиціонування себе як успішного міжнародного політика, вдаючись до протиставлення «було погано до мого президентства, стало добре - $з$ моїм приходом» (Now a whole different story): «Syria was loaded with ISIS until I came along; I inherited a total mess in Syria and Afghanistan; Iran is in financial chaos now because of the sanctions and Iran Deal termination; at the end of the previous administration, relationship was horrendous and very bad things were about to happen. Now a whole different story. I look forward to seeing Kim Jong Un shortly. Progress being made - big difference! When I became President, I $\underline{\text { SIS was out of }}$ control in Syria \& running rampant...».

Негативно-забарвлена лексика $є$ ефективним персуазивним засобом, що його використовує Дональд Трамп для дискредитації своїх опонентів, демократів: «Schumer and the Democrats are big fans of being weak and passive with Iran. They have no clue as to the danger they would be inflicting on our Country.»

Критикує Трамп і зовнішню політику попереднього президента, називаючи конфлікти в Сирії і Афганістані «безкінечними війнами»: I inherited a total mess in Syria and Afghanistan, the "Endless Wars" of unlimited spending and death.

Стосовно міжнародних подій не завжди президент США використовує лише негативно-забарвлені лексеми. Так, його ставлення до політичної ситуації в Венесуелі відображене в таких позитивних лексичних одиницях, як freedom, democracy: «... Large protests all across Venezuela today against Maduro. The fight for freedom has begun!» "Spoke today with Venezuelan Interim President Juan Guaido to congratulate him on his historic assumption of the presidency and reinforced strong United States support for Venezuela's fight to regain its democracy....».

Позитивно-забарвлена лексика часто зустрічається на офіційній сторінці Дональда Трампа в постах, які відображають його політичне бачення місця США в світі, зокрема, вивід військ 3 Сирії він назвав «мудрим використанням грошей»: Syria was loaded with ISIS until I came along. We will soon have destroyed $100 \%$ of the Caliphate, but will be watching them closely. It is now time to start coming home and, after many years, spending our money wisely.

Задоволення Трампа від результатів економічних переговорів з Китаєм також виражене позитивними лексемами (good intent and spirit): China's top trade negotiators are in the U.S. meeting with our representatives. Meetings are going well 
Міжнародні відносини: теоретико-практичні аспекти

Випуск 4 (2019)

ISSN (print) 2616-745X; ISSN (online) 2616-7794

with good intent and spirit on both sides. China does not want an increase in Tariffs and feels they will do much better if they make a deal.»

Використання фразових дієслів та колоквіалізмів допомагає створити фамільярну тональність і наблизити мовлення президента до просторіччя, що $\epsilon$ безпрограшним персуазивним ходом: «Looking for China to open their Markets...»; "With a Wall it would be soooo much easier and less expensive»; "We added 304,000 jobs, which was a shocker to a lot of people».

Улюбленим граматичним засобом персуазивності Дональда Трампа варто назвати вживання вищого та найвищого ступеня порівняння прикметників та прислівників, які одночасно виражають гіперболізованість його оцінок. Часто гіпербола зустрічається у висловленнях-вихваляннях: «We have, by far, the strongest economy in the world!» "Done more in first two years than any President!» «North Korea relationship is best it has ever been with U.S. Jens Stoltenberg, NATO Secretary General, just stated that because of me NATO has been able to raise far more money than ever before from its members after many years of decline.»

Практично в кожному твіті американського президента зустрічаємо окличні речення, що демонструють його категоричний, подекуди ультимативний стиль: «We have, by far, the strongest economy in the world!» Часто Трамп використовує окличні речення в персуазивній стратегії дискредитації свого політичного опонента:«Democrats are becoming the Party of late term abortion, high taxes, Open Borders and Crime!»«Dems put us in a bad place - but now good!» Знаками оклику супроводжуються безапеляційні заяви про необхідність побудови стіни на кордоні з Мексикою: «With a Wall it would be sooоо тисh easier and less expensive.» «Being Built!» «Wall is being built!» «Lets just call them WALLS from now on and stop playing political games! A WALL is a WALL!» «The Wall is getting done one way or the other!»

Емоційність мовлення Дональда Трампа знаходить відображення у використанні ним графічних засобів персуазивного впливу, зокрема капіталізації ключових слів таких, як WALL, JOBS, DRUGS тощо. Графічно виділяє політик й інтенсифікатори, які самі по собі $є$ персуазивними: «...I would suggest you read the COMPLETE testimony from Tuesday.» «....China's representatives and I are trying to do a complete deal, leaving NOTHING unresolved on the table.» "Since ending the terrible Iran Nuclear Deal, they are MUCH different, but....» "After all that I have done for the Military, our great Veterans, Judges (99), Justices (2), Tax \& Regulation Cuts, the Economy, Energy, Trade \& MUCH MORE does anybody really think I won't build the WALL?»

Подекуди Трамп капіталізує цілі речення, зокрема лозунг, який він використовував ще під час передвиборчої кампанії: «MAKE AMERICA GREAT AGAIN!» 
Використовує президент США і модальні дієслова, проте здебільшого в різких іронічних слоганах, спрямованих на внутрішні сили, зокрема розвідку, якій він радить порозумнішати та повернутися назад до школи: «Certain people must get smart! Perhaps Intelligence should go back to school!»

Що ж стосується стилістичних засобів персуазивності, які є досить характерними для дипломатичної риторики, вони практично не зустрічаються в мініпостах президента. Так, евфемізми часто використовують в політичній комунікації, проте для різкого і часто грубого Дональда Трампа їх, здається, не існує. Серед небагатьох стилістичних засобів зустрічаємо подекуди оцінні enimemu: unlimited spending and death, Endless Wars, false narrative, distorted press тощо; повтори: «We added 304,000 jobs, which was a shocker to a lot of people. It wasn't a shocker to me.» «More troops being sent to the Southern Border to stop the attempted Invasion of Illegals, through large Caravans, into our Country. We have stopped the previous Caravans, and we will stop these also.» «Lets just call them WALLS from now on and stop playing political games! A WALL is a WALL!»; асонанс: Invasion of Illegals.

Розглянемо ілюстрацію щоденного спілкування, вилучену нами зі сторінки в Твіттері (Donald J. Trump):«.... a source of potential danger and conflict. They are testing Rockets (last week) and more, and are coming very close to the edge. There economy is now crashing, which is the only thing holding them back. Be careful of Iran. Perhaps Intelligence should go back to school!»

Серед експліцитних засобів персуазивності в наведеному фрагменті спостерігаємо використання модального дієслова should, яке підсилене використанням його в окличному реченні, а також наказовим реченням (Be careful of Iran). Досить дієвим $є$ використання стертих метафор (a source of potential danger and conflict; economy is now crashing; coming very close to the edge), притаманне американському політику.

Імпліцитне протиставлення «свої-чужі» (США-Іран) здійснюється за допомогою особових займенників (they, them) і доповнюється вживанням емоційно-оцінної лексики негативної конотації (danger and conflict; crashing) тощо.

Висновки 3 даного дослідження і перспективи подальшого розвитку

Цифровий публічний дипломатичний дискурс або твіпломасі є персуазивним типом дискурсу. Віртуальна комунікація на своїй сторінці в Twitter дозволяє президенту США Дональду Трампу формувати зовнішню політику країни на догоду своїм прихильникам серед американських виборців. Це дипломатія, яка відрізняється непередбачуваністю і визначає глобальний політичний клімат. Основним ï інструментом $є$ твіт, короткий текст- 
повідомлення, що включає лексичні, граматичні, стилістичні та графічні засоби персуазивності.

Підсумовуючи, зазначимо, що цифрова публічна дипломатія стає дедалі впливовішим персуазивним засобом міжнародної політики. Мовні засоби реалізації персуазивних стратегій і тактик $\epsilon$ надзвичайно ефективними в віртуальному середовищі, оскільки дозволяють практично миттєво апелювати до логіки та емоцій читачів по всьому світі, а отже стають інструментом міжнародного впливу. Так, влада Південної Кореї ввела в міністерстві закордонних справ посаду відповідального за Twitter, що свідчить про новий рівень розвитку дипломатичних відносин в соціальних мережах. Перспективними вбачаємо дослідження віртуальної мовної особистості дипломатів та видатних міжнародних діячів.

\section{References:}

1. Azhezh, K. (2006). Chelovek govorjashhij: Vklad lingvistiki v gumanitarnye nauki [The Speaking Human: The Contribution of Linguistics to Humanitarian Sciences]. Moscow: Editorial URSS.

2. Burkart, R. (1998): Kommunikationswissenschaft. Grundlagen und Problemfelder. Umrisse einer interdisziplinären Sozialwissenschaft. Wien.

3. Chernjavskaja, V.E. (2006). 'Diskurs vlasti i vlast' diskursa: problemy rechevogo vozdejstvija' [Discourse of Power and Discourse Power: Issues of Speech Influence]. Moscow: Flinta: Nauka.

4. Cull, N. J. (2006). 'Public Diplomacy» Before Gullion: The Evolution of a Phrase'. USCCenter on Public Diplomacy, [online]. Available at: https://www.uscpublicdiplomacy.org/blog/public-diplomacy-gullion-evolutionphrase [Accessed 27 February 2019].

5. Donald J. Trump. Twitter, [online]. Available at: https://twitter.com/realDonaldTrump?ref_src=twsrc\%5Egoogle\%7Ctwcamp\%5Eser p\%7Ctwgr\%5Eauthor [Accessed 04 March 2019].

6. Edsall, T. B. (2015). 'Euro-Trump'. The New York Times, [online]. Available at: $\quad$ https://www.nytimes.com/2015/11/18/opinion/campaign-stops/eurotrump.html [Accessed 05 March 2019].

7. Golodnov, A.V. (2003). Lingvopragmaticheskie osobennosti persuazivnoj kommunikacii (na primere sovremennoj nemeckoj azychnoj reklamy) [Linguistic and Pragmatic features of Persuasive Communication (Based on Contemporary GermanLanguage Advertising)].D.Ed. Herzen State Pedagogical University of Russia, St. Petersburg.

8. Halliday, M.A.K. (1978). Language as Social Semiotic: The Social Interpretation of Language and Meaning. London: Arnold. 
9. Jäckel, M. (1995). 'Interaktion. Soziologische Anmerkungen zu einem Begriff'. Rundfunk und Fernsehen, no. 43, pp.463-476.

10. Karasik, V. I. (2002). Jazykovoj krug: lichnost', koncepty, diskurs [Language Circle: Personality, Concepts, Discourse]. Volgograd: Peremena.

11. Landale, J. (2018). 'Shcho take dyplomatiia "vohniu i liuti" Donalda Trampa' [What is Donald Tramp's "Fire and Fury" Diplomacy]. BBC, [online]. Available at: https://www.bbc.com/ukrainian/features-44507538 [Accessed 25 February 2019].

12. Merten, K. (1977). Kommunikation. Eine Begriffs- und Prozessanalyse. Opladen.

13. Perelman, Ch. (2000). A New Rhetoric: A Treatise on Argumentation. Notre Dame (Ind.): Univ. of Notre Dame Press.

14. Pocheptsov, G. G. (2001). Kommunikativnye tehnologii XX veka [Communicative Technologies of the XX century]. Moscow :Refl-Buk; Kiev : Vakler

15. Skriabina, V. B. (2018). 'Linhvistychni aspekty persuazyvnosti v dyplomatychnomu dyskursi' [Linguistic Aspects of Persuasion in Diplomatic Discourse]. Mizhnarodni vidnosyny: teoretyko-praktychni aspekty [International Relations: Theory and Practical Aspects], issue 2, pp. 93-98. DOI: 10.31866/2616745x.2.2018.133362.

16. Terentij, L. M. (2010). 'Diplomaticheskij diskurs kakosobaja forma politicheskojkommunikacii' [Diplomatic discourse as a Special Form of Political Communication]. Voprosy Kognitivnoi Lingvistiki [Questions of Cognitive Linguistics], no. 1. pp.47-56.

17. Trophymenko, M., Balabanov, K. (2013). 'Publichna dyplomatiia» yak vidpovid na vyklyky suchasnosti' [Public Diplomacy as a Solution to Modern Challenges]. Ukraina Dyplomatychna [Diplomatic Ukraine], issue 14, pp. 989-1007.

(C) Скрябіна В. Б., 2019 